\title{
A Study in the Future of the Transition to the Federal Budget of the Federal Iraqi State
}

\author{
Koh Igor Anatolevich ${ }^{1}$, Wisam Sami Mohsin Al-Luhaibi ${ }^{2}$ \\ Department of Financial Markets and Financial Institutions. \\ Kazan University, St.Kremlevskaya 18, Main Building of KFU, 420008,Kazan, Russia
}

\begin{abstract}
The Iraqi experience suffers from the ambiguity of the transition towards planning fiscal public policies from traditional budgets to the federal budget during the coming years, because of the incompleteness and full maturity of the federal administrative system, and on the other hand, the non-oil sectors of the Iraqi economy still suffer from many problems. Despite that, the Iraqi economic situation is still suffering from the combination of performance, the cautious rush towards development and the problem of unilateral rent, which could be a real obstacle to the emergence of this kind of financial budget. The transition to the implementation of the general policy of the Iraqi federal state towards the federal budget pattern will be an entry point towards the emergence of a solid local economy. This economy is capable of managing the Iraqi self in a manner able to use all the tools of production and competition between the local governments of the regions and governorates that are not organized in a region in order to achieve discrimination and economic prosperity for the federal state. Since federal Iraq will move towards using the federal budget instead of the current federal budget, the current research provides a detailed study of many practices of fiscal federalism in a group of federal states despite their differences in terms of managing financial imbalances, sources of revenues and expenditures, and the degree of financial independence for local governments.
\end{abstract}

Keywords: Federal Budget, Fiscal Federalism, Fiscal Public Policies. 


\section{Introduction}

The budget is one of the most important planning tools, and it is a translation of the country's goals, policies, and plans in the form of numerical numbers, which are the basis for workflow and progress. The budget also binds every sub-administrative unit in the facility to develop plans that are in line with other plans and do not contradict them. Therefore, it is an important formatting tool. It is also a tool for determining responsibility and authority. The sales planning budget, for example, defines the responsibility, authority, and activity of the sales department. In addition, the production-planning budget, determines the responsibility, authority, activity, and so on of the production management. If the budget is a planning tool, then a control tool helps the state's financial management to achieve the control function, because it indicates what is required to be implement, and what has been implemented. As such, it is a tool for monitoring government activity, and evaluating its performance, to determine the progress of work, and the extent of its conformity with the set plan.

The budget links all jobs in the state, with a comprehensive plan, expressing the best programs, which the officials see, so that all workers work in precise harmony and coordination, avoiding contradictions in the sub-goals of the various departments, divisions and production units, to achieve the main goals. Since federal Iraq will move towards using federal budgets instead of the current federal budget, there is a need to study many practices of fiscal federalism in a group of federal countries represented by (Australia, Brazil, Canada, Germany, India, Malaysia, Nigeria, Russia, South Africa, Spain, Switzerland and the United States of America) [Anderson,2007].

These countries differ in terms of managing the horizontal and vertical financial imbalance, sources of revenues and expenditures in each of the administrative units that make up the federal state, and the degree of financial independence for local governments (province or region) or interference by the federal government in managing the financial systems of local or state governments, and the federal system. The region plays an important role in shaping the general shape of the federal budget of the federal state. 


\section{The Financial Budget Of The State}

\subsection{The Philosophy of Balancing}

Among the most important goals of modern scientific management, at the level of the economic unit or the state as a whole, is the optimal use of material and human energies, and the development of the largest amount of resources, in order to achieve the objectives of the project, which are part of the goals of society. The budget is prepared, by planning resources and uses, for a future financial period, considering the circumstances surrounding the economic unit, which have expected to be effective during that period [Hasheesh,2006]. Then the actual implementation of the laid plan has monitored, to achieve the goals. If the actual implementation deviates from the set plan, then the management takes the corrected decisions immediately, so that the deviation does not accumulate and losses increase, so the budget requires:

1. Planning a coordinated policy.

2. Implementing the plan and controlling it.

3. Taking corrective decisions, for any deviations, and treating their causes.

Thus, the economic unit works, while it is safe from economic fluctuations, in advance, to face the expected obstacles and expected dangers.

The budget method differs, under the planned economic system, from the capitalist economic system, in terms of the extent to which the economic unity plan has linked to the state's general plan. Under the planned economic system, the plan of economic unity has linked to the general plan of the state. While the plan of economic unity that operates under the capitalist system is not linked to the general plan of the state. Apart from this difference, the idea of planning and control is applicable in the two systems. The budget is a numerical expression (quantitative and quantitative), of the activity plan related to a future financial period, a means for effective control of implementation, and a tool through which the executive responsibilities are distributed among the employees, so that performance can be evaluated, implementation follow-up, and the achievement of set goals can be verified, and the required decisions are taken. Through this procedure, the budget helps to enable the administration to carry out its mission, in a manner of "Management by Exceptions", meaning 
that the administration directs its attention to what is outside the plan, thus leaving the routine matters that proceed naturally, without wasting their time directly, etc [Hilali,2002].

\subsection{Financial Budgets}

The responsibility for preparing budgets has carried out through a special committee, which represents the main ministries in the country, called the "budget committee" and often includes managers, whose work has affected by it, to ensure coordination between the various departments. When preparing budgets, two types should distinguish Budget for ongoing operations, and the investment budget (capital investment spending, to add new energies). The preparation of both budgets includes several sub-budgets. As for the basic steps that have followed in preparing budgets, they are as follows:

The first step: Determine the desired objectives of the plan

During the budget period, the desired main objectives of the plan have been defined before the detailed programs begin. And when setting goals, taking into account that the goals are achievable, taking into account the internal conditions of the facility and the external factors surrounding it, setting the goals of the theory of theoretical goals or ideal goals leads to demotivation, and the entire budget is viewed as impossible to implement. The goals set in the next plan are better than the goals that had actually achieved in the previous plan, and in the case of multiple goals, it is necessary to determine the relative importance of each goal, thus avoiding interest in the sub-goals at the expense of the main goals [Al-Jabali,2008].

The second step: developing sub-plans and preparing the estimated budget lists.

The budget consists, in its final form, of a series of detailed sub-plans, and coherent and interconnected estimated lists. The number of detailed plans being prepared may vary from unit to unit. The elaboration of detailed plans and the preparation of the estimated lists of the budget include several successive steps, and one of these important steps is defining the production program for the economic unit, and the succession of other steps related to determining the production requirements of raw materials, and other aspects of spending.

The third step: coordination between sub-plans.

It is necessary, after preparing the proposed sub-plans, during the budget period, to coordinate these plans in order to achieve complete harmony between them, and so that 
bottlenecks can be discovered and addressed, which arise as a result of the lack of balance between the different aspects of activity in the economic unit. The coordination between the parts of the budget may require the need to amend some sub-plans. It may become apparent, during the coordination process that some interrelationships between the sub-plans have not considered. For example, it becomes clear that the estimated expenditures for maintenance do not comply with the technical conditions for regular maintenance required by the production program during the budget period, or that the estimated expenditures of the marketing service centers are not sufficient to dispose of the products of the economic unit. As might be evident from coordination, the estimates are inconsistent with the project's potential [Al-Jabali,2007]. The fourth step: approving and issuing the budget.

In issuing the budget in accordance with the Iraqi constitution, the budget has approved to form a committee from the Ministry of Finance and Planning and the responsible ministries that work to estimate the size of the expected annual revenues and the size of the requirements depending on the size of public spending for the current fiscal year. Then it has submitted to the Council of Ministers for discussion, review, and approval and sending it to Parliament In order to discuss it, then approve and vote on it, and then ratify it by the Presidency of the Republic and publish it in the official newspaper (Al-Waqi'a Al-Iraqiya) for its implementation. If we are talking about the budget of the current operations and the investment budget, then when preparing the budget for the current operations, the concern is mainly in forecasting revenues, making use of the available production capacity, determining the production and inventory program, and determining production requirements during the budget period. Focuses on capital formation, such as: establishing new factories, replacing and renewing fixed assets, continuous creative search for new and available opportunities for investment, and setting a differential arrangement for investment projects, by measuring the economic value of these projects [USAID, 2008]. 


\subsection{The public budget}

The public budget has defined as "a detailed and approved estimate of public expenditures and public revenues, for a future financial period, often a year." The state budget is of great importance because it expresses the political, economic, and social work program of the government during the financial period [Al-Buraihi,2008]. In other words, the state's general budget has political, economic, and social connotations. The various objectives of the state have be revealed, by analyzing the public revenues and public expenditures figures, which have combined by one document, which is the state's general budget. In short, it can be said that the state's general budget is not just a statement that includes public revenues and public expenditures, but rather is closely related to the national economy and the main tool through which the state is political, economic and social goals can be achieved [Atvi,2003].

The public finance scholars agreed that preparing the state's general budget must be subject to a set of rules aimed at setting the budget in a clear manner, in order to facilitate the legislative authority's understanding of it, and then impose oversight on its implementation. These rules also aim to ensure that the general budget is an honest expression of the state's financial activity [Almendral,2007]. In addition, these rules avoid wrong government and reduce the possibility of wastage, especially in the case of increasing revenues over spending. There are five basic rules for the general budget:

First: The annual base.

This rule requires that the state's uses and resources have estimated for a future period of time, a period of one year, which may be identical to the calendar year, or overlap with it. As is the case in some countries, as the fiscal year begins on 1 July and ends at the end of June of the following year. The annual rule is one of the most stable principles when preparing the state's general budget, on the basis that the year represents a complete cycle of the four climatic seasons, then the expenditures and revenues during it have characterized by frequency, and the year is an appropriate period for evaluating the performance of the executive authority [Hammad,2005].

Second: The base of unity. 
The unit rule requires that all uses and resources of the various units of the state's executive apparatus be included in one budget, which helps to know the economic and financial conditions the state is going through, as well as the ease of exercising control, political and popular, during the stages of implementing the budget [Al-Basri\& AlBandar,2006].

Third: The general rule.

This rule requires that the general budget include all the resource and usage estimates, without a set-off between some of its chapters or its items and others. This is to achieve effective control over both the state's resources and their uses [USAID,2009].

Fourth: The rule of non-assignment.

Under this rule, it is impermissible to allocate specific resources to meet specific uses. The rule of non-allocation requires that all resources have directed to all uses, and therefore it is not permissible to allocate a specific resource, such as tax on cars, for example, to spend on the construction and maintenance of roads [Watts,2007].

Fifth: The equilibrium rule.

The equilibrium rule stipulates that uses (expenditures) should be equal with revenues, and despite the soundness of this rule. The changing and intertwined economic conditions in most countries of the world have led to the acceptance of the idea of a deficit or surplus in the public budget, as the deficit is covered by loans, local And international, and the surplus is carried over to the next period [International Monetary Fund,2001].

\section{Managing The Federal Budget In Multiple Forms}

There are many successful financial federalism practices in Australia, Brazil, Canada, Germany, India, Malaysia, Nigeria, Russia, South Africa, Spain, Switzerland and the United States of America. These countries differ in terms of managing the horizontal and vertical financial imbalance, the sources of revenues, and expenditures in each of the administrative units that make up the federal state And the degree of financial independence of local governments (province or region) or intervention by the federal government, and the federal system for the region plays an important role in shaping the general form of the federal budget [Salem,2009]. 


\section{First: Australia}

We find that there is an increase in the control of the central government in imposing taxes on the regions. The regions spend more than what is allocated to them, which creates a deficit in the budget. The central government tries to block the revenues obtained from government tax revenues, thus this led to a vertical imbalance in the management of the federal budget. The financial gap caused by immature policies by the plans of local governments has made the central government (the Commonwealth) work to provide grants as transfers of up to $40 \%$ of the total transfers in the form of specific-purpose payments in order to support the national goals of the state represented in strengthening the health sector, education and services and this I mean, there is a great balance in the horizontal distribution of the federal budget [Morris,2007].

Second: Brazil

Brazil has been working to follow a fiscal discipline law since 2000 by equating the domestic spending of state-owned enterprises represented in the region with the level of indebtedness of the local government. However, this generated an imbalance in the federal system of distribution of funds allocated to the budget, whether on the horizontal level or the vertical level, which made a greater role for the central government in managing the budget and determining the requirements for feeding or revenue. This situation prompted local governments to demand a review because of pressures, which created a financial system far from controlling currency rates through the national float of the market, and thus financial management for monetary stability relied on the administration responsible for financial accounts, so financial discipline replaced the exchange rate in order to avoid inflation.

Brazil has succeeded in curbing unsuccessful taxation, called "social contributions," as well as curbing conditional grants on local governments that disturb the realities of development. However, despite this, the challenges still present to the federal entity, represented by the specific powers of the regions or local governments, in making the financial budget decision, which must be reconsidered. Despite overcoming these challenges, the Brazilian financial federal system still suffers from an imbalance in the horizontal distribution of resources between the regions of the Amazon and the central-western and 
northern regions of Brazil, which affected public spending and investment to a particular degree [Resind,2007].

Third: Canada

It follows the classic system of fiscal federalism. The independent regional government is responsible for providing many public services, and has the right to collect hydrates, such as taxes, for example, in addition to financial collection through many unlimited means. As for the federal financial allocations, they follow the allocation of unconditional equality and equal transfers. Local governments can provide public services with high efficiency and close to national standards, in addition to homogeneity in taxation between the central government and local governments (income and sales tax), and all this created a successful economic system.

The driving factors are that the federal legislative trend for the regions gave them legislative capacity in health, education and social services in a way that makes the central government able to provide high-quality services. Therefore, the spending power strengthened the financial position of the federal districts.

The presence of resources has strengthened the means of employment, which gave priority to the region in imposing a specific tax on employment while giving the central government to manage the volume of parallel development in a manner equal to the size of the tax collected from the regions or provinces. There may be disparity in income from one province or state to another because of difference the size of the natural resources. The central federation has turned into a decentralization as a result the similarity in the central spending programs with the regions and districts. However, it faces one problem, which is in the event of a boycott's debt that has deducted from the size of government spending on social programs, which may generate a horizontal imbalance, which has prompted the regions or sectors to emphasize the Federal Council in order to stabilize the horizontal management of the volume of public spending.

Fourth: Germany

The federal system is a cooperative system based on 16 administrative units and that the federal decision-making takes place through the Bonstack Building (the Supreme Council 
"Parliament"), which gives the right to veto the provinces in determining government policies, which could make the Federal Council a closed council in the event of the formation of the political majority. The federal system succeeded in establishing control over the "district" administrative unit in determining the size of the tax. However, the federal financial system addressed the problem of the different diversity of resources, which called for strengthening the balance of parallel development management in order to achieve equality. Coordination between regions is sometimes turbulent, which means an impact on economic stability. This has done by reforming administrative powers, which means effective government intervention during crises [Feld \& Hagen,2007].

Fifth: India

The federal system has based on a system of intergovernmental financial arrangements between the center and the states, thus weaving a real clear cohesion. The constitution guarantees the size of the tax in terms of the center and the state, and the states have a major role in the systems of administration and providing competitive service with the center. Industrial and agricultural development and irrigation management represent one of the basic tasks of the states, and taxes have controlled by the central government, while we find marginal mobility for the states. As for the issue of borrowing, it is one of the powers of the central government after looking at the state's debt record, and it have be given through discussion the license to continue the debt. India still follows the planning method in the financial policies for dealing with the states in terms of monitoring the level of growth and equal distribution of wealth and income, in addition to bridging the joints of the state budget deficits.

The state was able to form the National Council for Development headed by the Prime Minister and a group of responsible ministries and a number of state presidents in order to provide grants for strategic projects at a rate of (16-17\%) of the size of the federal budget of the state. The President of the Republic works every five years to form a financial committee to review financial flows between the center and the states to conduct a real review of financial policies. Since the diversity of the spectrum of Indian society is a fundamental feature, the Indian political forces had a negative role because of the asymmetry in the performance of fiscal policy management and the interference in the technical powers of 
managing the federal budget, which made the entry of political forces into preparing and managing the budget [Rao,2007].

Sixth: Malaysia

Malaysian constitution has a very clear division of powers between the center, states and local governments. The concentration of tax administration in the hands of the central government has made there a great deal of hegemony over the management of the federal budget. The constitution sets severe restrictions on addressing the state's local budget imbalance and making its borrowing conditions sharp. Although the powers made the local governments have really given a role for local governments in imposing taxes on the management of mineral resources, it is not sufficient to fill the deficits in some states. Parallel development in the management of local governments has made federal governments highly capable in managing government policies, because of the central government bearing the costs of managing public life and financing capital and policies aimed at that, especially in the basic sectors of the state.

The success of the state in attracting investment by introducing a group or a package of strategic projects in the heavy industries and information technology sector made the central government with a real ability to run the state in a modern way, which made aspiration a basic title and the transition to follow the steps of financial growth. Despite the fact that contemporary capitalism was able to build a unique experience in the transformation of wealth from the public sector to the private through direct investment or privatization, but with the remains of the shares of most companies and a major part of them in the hands of the government of the public ownership of society "Modern companies".

In addition, local governments can establish companies and obtain financing for their projects through direct subscription in order to finance the cost of the project.

The federal state is committed to providing a "head grant" to each state according to the state's population census and a parallel grant for all infrastructure projects in order to develop national awareness. The problem of states is small, which makes the federal financial administration traditional, but in return, governments work to obtain investments to implement their strategic projects. Despite the endeavor to reduce support for petroleum in 
order to support long-term development projects, it has caused great discontent and real confusion in the management of the comprehensive development of the state[Rusli,2007].

Seventh: Nigeria

The financial federal system has greatly saved the country. There are 36 states and 774 local governments. The federal system has evolved so that the federal regions have created a constitution of their own in addition to the national constitution of the state. However, the 1966 coup affected this, but despite that, the federal financial system is still one of the basic features of the state. Although the federal financial system has worked to give broad powers to the regions in order to achieve development and urge them to use financial resources for the purpose of comprehensive development, the control of the central government in the conduct of financial management is still evident and influential in the management of the financial system [Baudway,2007].

One of the important issues is "the issue of financial derivation" in managing the financial returns of the federal regions by returning $13 \%$ of the volume of oil revenues to the central treasury by dividing the triple revenue in the West, North, and East when agriculture was $50 \%$.

The management of oil revenues is still a confusion for the country's experts because of the neglect of the oil regions because of their small population and the work to provide financial resources through oil revenues, and this is what deprived these areas of sustainable development. Therefore, the states have called upon to participate in the proceeds of the money obtained from the sale of the extracted oil to create a new joint of development based on revenue sharing. Therefore, opinions had gathered on:

1. Adoption of a unified concept of derivation.

2. Giving an appropriate weight to equality between states.

3. Giving appropriate attention to developing areas of natural resource production.

4. Participation in building resources on the responsibilities of each level of government.

The Fiscal Responsibility Law to achieve a fair balance in managing development programs and making the budget a balance of goals and responsibility [Ikbo,2007].

Eighth: Russian Federation 
There is a problem with the transition from political to financial federalism. Russia is implementing a system of revenue independence in terms of component units. The political perception of federalism made the central government work to give unspecified powers in order to preserve the Russian entity, and the government rushed to implement a federal financial system in order to control the mechanism of symmetry in performance and economic growth, and worked to change political powers to decentralization while giving a new type of change In the financial perceptions by assigning a specific type of responsibilities to each region for the sake of legislative compatibility in financial legislation. After 2004, the government worked on a serious measure to focus political power [Eugene \& Andeskaya, 2007].

The shift towards financial federal performance gave the president the powers to monitor and manage the performance of the financial budget. So that if there were a defect in performance, the president would intervene in financial management through the manufacture of what had known as joint federal-regional specializations, and the tax consisted of 50 federal types, while local taxes did not exceed two. Despite the development in the local authorities in developing the volume of revenues, the government still stuck to innovating participation formulas or working to change them according to the supreme strategic interest of the state. There is a disparity in the distribution of income within Russia because of the effects of the previous economic system. The asymmetric federal system in terms of financial performance and management based on the local thinking style without the state made financial federalism in terms of giving responsibilities the effective title in terms of performance and application. Ideas clash between political federalism - fiscal federalism, but they believe that strengthening fiscal federalism will strengthen political federalism [Benacher $\&$ Austein,2007].

Ninth: South Africa

Although the federal financial system has followed, the parallel development process was not the primary goal in managing the federal budget, affecting the national, regional and local areas, and the regional administration has financed through the revenue sharing model. Federal programs have funded through hydrides from the federal districts through a fair 
regional share, in addition to the target programs, and a fair share has created for the local government.

The major municipalities can finance projects and the size of expenditures, while the smaller ones need central support through taxes, the tax problem is facing -

1. The lack of an effective accounting system.

2. A historical legacy of distrust of the services provided towards the tax, which strengthens the culture of tax evasion

Intergovernmental financial relations have characterized by relative centrality of revenues in South Africa, with a high proportion of decentralized spending.

The government has worked on:

1. Development of the Capabilities System

2. Empowering human resources to manage the federal and local financial budgets

3. Development of financial auditing capabilities

4. Improving the fiscal tax collection system

5. Providing a minimum level of basic services to the citizen, and in the event of enhancing the volume of services, the financial acquisition fees are raised, but in small proportions, whether in terms of services or hospitals

Building the federal budget according to:

- The vertical division: which takes place between the 9 provinces and the 284 municipalities through interest in developing strategic services, which reflects the relative priority assigned to each level of government.

- Horizontal division: based on a specific equation that takes into account demographic factors and economic activity [Mokatti,2007].

Tenth: Spain

The year 1978 represented a new development in the Spanish financial system and its transition to the financial decentralization system, which led to the formation of three levels of government against the central and local levels. Fiscal federalism has succeeded in the areas of spending and revenue collection for you. Other responsibilities have still not completed, especially in the areas of financial responsibility, financial equality, and financial relations. 
The autonomous states manage public spending by $35 \%$ of public spending by providing all services except for social and personal services and other less expensive services.

The financial maturity of local governments and state councils is still so immature that the tax collection process is still suffering from real and confused problems in terms of performance of the development of services provided to the taxpayer. The Spanish centralized financial system contains two financial systems, the first applied in 15 states, including the states that have autonomy, including the Basque Country and Navarre, through the adoption of special tax systems that encourage companies, which makes the similarity of tools for fiscal policy not available in these special regions. Throughout the Basic Financing Act for Autonomous Communities, and there is tax participation and revenue sharing for added tax and transfer taxes, we find that the fiscal powers are asymmetric [Villanova,2007].

Eleven: Switzerland

The financial system is federal, independent, and a system capable of dealing with administrative units without federalism, especially after the adoption of the Financial Equality Act, which has been in effect since 2008, in addition to the means available to encourage fiscal responsibility between the cantons (provinces). The provinces have greater tax capacity than the largest state in the world except for the United States of America

The government enjoys direct democracy at every level of government (meaning that the citizen, i.e. the voter, is able to directly object or petition any government law after collecting sufficient signatures within the Swiss constitution in order to achieve financial and social equality. Fierce tax competition, which may be progressive according to the size of the population and the economic position, in order to redistribute income. As for financial reform to support the poorest provinces, the size of the per capita income has estimated at $85 \%$ of the national average, and financial rescue policies have followed because of the asymmetry in the practice of managing the federal financial policy [Anderson,2007].

Following a sustainable financial policy to perpetuate the equitable distribution of income by allowing a financial referendum for the citizen by stopping the government or parliament from undertaking any proposed expenditures. As well as by restraining the debt, which will allow the use of the financial cycle in times of crisis or the treatment of the 
financial deficit in a subsequent year after the financial surplus that could be used in subsequent investment projects was transferred to the treasury. The idea of government intervention is cautious in the case of fiscal deficits of the provinces [Krechsner \& ARA,2007].

Twelve: The United States of America

The federal financial system is a balanced system between three relatively independent levels of government (federalism, states, and local authorities). Local authorities are the body responsible for providing public services and have the power to impose taxes, while the US Constitution defines two levels, the state, and the federal level. The third role is a role defined by the states, i.e. local governments. The courts play a role in resolving disputes between the states and the federal level (the federal government) and has been shown to be effective in equilibrium. The problems are government programs to balance federal and state revenue restrictions after the increasing cost of programs, the increasing demand for services by the public and economic trends, but federal programs have implemented through the state government. Temporary reform by the states destroys the state's fiscal budget and reaches a breaking point after inflation. Programs have planned by the federal government and the state to implement these programs. Social initiatives include issues of child and security management. The federal financial system regulates foreign trade, taxation, and regulation of interstate relations, debt payment, and a welfare society.

The constitution guarantees secondary powers in the implementation and administration of programs and addresses the imbalance in the federal budget by reducing support for development programs for the federal states. The federal government controls the administration of the federal budget even though the constitution has ensured ways to activate the state government's role in managing and planning implementation mechanisms for spending the federal budget and summarizing its targeted programs. The balance of powers is still imbalanced between the federal and state governments [Hackpart,2007]. 


\section{Evaluating The Strategic Performance Again}

Building the federal budget according to the general policy philosophy of the federal Iraqi state requires the following:

1. Working on redesigning the financial policies according to very advanced powers and legal legislations and instructions explaining this federal design in Iraq.

2. Iraq needs 1 - 6 years to build a federal budget that is consistent with the requirements of the federal system and the path of development to have applied in Iraq.

3. The division of powers between the federal state and the federal regions or governorates is not organized in region $\mathrm{N}$, and this will be done through: -

\subsection{The trend towards the hourglass model in the federal financial systems}

That is, rebuilding the mechanisms of the transition towards managing the federal budget in terms of transferring powers from the center to the regions and governorates that have not organized in a region [Shah,2007].

\subsection{Building a new vision for local government}

It has done for you through an insightful interpretation of the legal legislation, whether in the Federal Iraqi Constitution of 2005 or the laws governing the formation of federal regions, while looking into building the law on the federal regions. Work to build balanced and mature financial policies capable of reducing poverty levels in the case of applying the federal financial systems of the federal Iraqi state by focusing on the main humanitarian needs, food, housing, education and health, as they represent sensitive issues for the Iraqi national security in the federal state. Spreading the values of rationality in the strategic performance of managing public policies in implementing the financial budget by the formed units in the federal Iraqi state n. This has done through clarity of financial legislation and finding effective communication channels and has the ability to hold periodic performance review meetings in order to activate the principle of cooperation between the authorities the federal government and the local government or the provincial council for a governorate that has not organized in a region.

Managing intergovernmental competition in a way that achieves fairness and equality in performance. Therefore, the federal authority is trying to build military bases, attract huge 
investments and finance federal infrastructure projects, in return, the regions and local governments compete to manage and prosper their local economies. And thus coordination between the federal government and the local government or the federal government of the region will strengthen Managing competition and moving it from the logic of "make the region poor and the center rich" to a creative image that calls for "work together for prosperity" for the federal state.

\section{Conclusion}

It is clear from the above that Iraq today is going through the transitional phase to build the local authority after it was able to install the constitutional institutions and statebuilding structures. Thus the second phase of construction, which may be in the management of the local government of the state and the people, or work to transform within the framework of the powers of the provincial councils in order to develop the use of fiscal public policies in accordance with the federal budget of the state. However, Iraq will continue to suffer from the infrastructure for the emergence of regions or governorates that have not organized yet. Despite this, the philosophy will come without the framework of an executive structure. The choice will remain in the hands of the decision-maker and its political blocs, in addition to the people's voice in choosing options for transition to manage fiscal policy in the light of the contemporary Iraqi federal state. 


\section{Acknowledgment}

The work is performed according to the Russian Government Program of Competitive Growth of Kazan Federal University.

\section{References}

[1] Abdel Fattah Al-Jabali, "Fiscal Policy in the First Decade of the 21st Century," a background paper presented in the National Planning Institute's Second Annual Report 2008 .

[2] Abdel Fattah Al-Jabali, Local Government Debt in Egypt, Causes and Solutions, Strategic Brochures, Year 9, Issue 77, Center for Policy and Strategic Research A1Ahram, 2007.

[3] Akban H. Ikbo, Nigeria's Fiscal Federalism: Unresolved Issues, edited by Raoul Blind Benaher and Abigail Ostain, Dialogues on Tax Federalism Practices: A Comparative Perspective, EM translation for Arabic translation, Federation of Federations Forum, Canada, 2007.

[4] Alan Morris, Australia: The Doctrine of Justice, Imbalance and Equality, edited by Raoul Blind Benacher and Abigail Ostine, Dialogues on Fiscal Federalism Practices: A Comparative Perspective, EM translation for Arabic translation, Federation of Federations Forum, Canada, 2007.

[5] Alexander Eugene and Galina Kerley Andeskaya, Russian Federation at the Crossroads, in the book edited by Raul Blind Pinacher and Abigail Ostein, Dialogues on the Practice of Fiscal Federalism: Comparative Perspectives, translation by AM Company for Arabic Translation, Federation of Federations Forum, Canada, 2007.

[6] Anwar Shah, Comparative Reflections on the New Challenges of Fiscal Federalism, in the edited book by Raoul Blind Banacher and Abigail Austin, Dialogues on the Practice of Fiscal Federalism: A Comparative Perspective, EM translation for Arabic translation, Forum of Federations, Canada, 2007. 
[7] Dr. Adel Ahmed Hasheesh, Fundamentals of Financial Art for the Public Economy: An Introduction to Learning Fundamentals of Public Finance, El Jadid University of Publications, Alexandria, Alexandria, 2006.

[8] Dr. Ahmad Al-Buraihi, Federation of Financial and Petroleum Resources of Iraq, AlHiwar Magazine, Issue 17, Progress Development Policy Institute, Baghdad, 2008.

[9] Dr. Akram Hammad, Government Accountability and its Application in Palestinian National Authority Ministries, Afaq for Printing and Publishing, Palestine, 2005.

[10] Dr. Imad Abd al-Latif Salem, Preparation, Discussion, and Approval of the Federal Budget in Iraq, Al-Hivar al-Muhammad website, 2009.

[11] Dr. Kamal Al-Basri and Dr. Abdullah Al-Bandar, Federalism, Constitution and Economic Issues, Amman, 2006.

[12] Dr. Muhammad Jamal Ali Hilali, Government Accounting and Its Applications, Dar Al-Safa for Publishing, Amman, 2002.

[13] Dr. Violetta Ruiz Almendral, Financial Federalism, Forum of Federations, Amman, 2007.

[14] Edited by Raoul Blind Benacher and Abigail Austein, Dialogues on the Practice of Fiscal Federalism: A Comparative Perspective, translated by E.M. for Arabic translation, Forum of the Federation of Federations, Canada, 2007.

[15] Fawzi Atvi, Public Finance: Tax Systems and the Government Budget, Al-Halabi Legal Publications, 2003.

[16] Fernando Resind, Brazil: Maintaining Fiscal Discipline in the Context of Regional and Social Antagonism, edited by Raoul Blind Benacher and Abigail Austin, Dialogues on Fiscal Federalism Practices: A Comparative Perspective, EM translation for Arabic translation, Federation of Federations Forum, Canada, 2007.

[17] Gebhard Krechsner and Prabow Gobt ARA, Sustainable PFM with Sub-Federal Financial Independence: The Case of Switzerland, edited by Raoul Blind Benacher and Abigail Ostain, Dialogues on Fiscal Federalism Practices: Comparative Views, EM translation for Arabic translation Forum of the Federation of Federations, Canada. 2007. 
[18] George Anderson, An Introduction to Federalism, translated by Maha Takla, edited and revised by Maha Bastani and Mary Joel Zahar, Forum of Federations, Canada, 2007.

[19] International Monetary Fund, revised version of the Financial Transparency Guidelines, February 2001.

[20] Joaquim Sule Villanova, Spain: Rethinking Financial Equality and Financial Relationships, edited by Raoul Blind Benacher and Abigail Ostain, Dialogues on Fiscal Federalism Practices: A Comparative Perspective, EM translation for Arabic translation, Forum of Federations, Canada, 2007.

[21] Lars B. Feld and Jürgen von Hagen, Techniques for Reforming German Tax Federalism, in Raoul Blind Benacher and Abigail Ostain's Edited Dialogues on Tax Federalism Practices: A Comparative Perspective, EM translation for Arabic translation, Forum of Federations,2007.

[22] Local Government Program / 2, Iraqi Government's Federal Budget Procedures: Investment Budget, USAID, 2008.

[23] Local Government Program, Preparing Provincial Financial Budgets, USAID, 2009.

[24] M. Govinda Rao, Fiscal Federalism in India: New Challenges, edited by Raoul Blind Benacher and Abigail Ostine, Conversations on the Practice of Fiscal Federalism: A Comparative Perspective, EM translation for Arabic translation, Federation of Federations Forum, Canada, 2007.

[25] Merle Hackpart, The Changing State of Fiscal Federalism in the United States, edited by Raoul Blind Benacher and Abigail Austine, Dialogues on Tax Federalism Practices: A Comparative Perspective, EM translation in Arabic, Forum of Federations, Canada, 2007.

[26] Renussi Mokatti, South Africa: Fiscal Federalism in Transition, in the edited book by Raoul Blind Benacher and Abigail Ostein, Dialogues on the Practice of Fiscal Federalism: A Comparative Perspective, AM Company Translation for Arabic Translation, Forum of Federations, Canada, 2007.

[27] Robin Baudway, Canada: Emerging Challenges in Decentralizing Federalism, edited by Raoul Blind Benacher and Abigail Austein, Dialogues on Fiscal Federalism 
Practices: A Comparative Perspective, EM translation for Arabic translation, Forum of Federations, Canada, 2007.

[28] Ronald L. Watts, Federal Regulations, translated by Gali Barkhumi, Maha Takla and Maha Bustami, Federations, Forum of Federations, Canada, 2007.

[29] Saif Al-Azhar Rusli, Malaysia's Fiscal Federalism: Challenges and Expectations, in a book edited by Raoul Blind Benacher and Abigail Austin, Dialogues on Fiscal Federalism Practices: A Comparative Perspective, translated by AM Company for Arabic translation, Federation. Forum, Canada, 2007. 